\title{
Creative activity approach in teaching English language for medical students
}

\author{
Irina Borisova*, Varvara Maksimova, and Oksana Dmitrieva
}

Institute of Foreign Philology and Regional Studies of M.K. Ammosov North-Eastern Federal University, 58 Belinskogo street, Yakutsk, 677000, Russia

\begin{abstract}
The paper addresses the creative activity approach in teaching English language for medical students of the first and second years. Activation of the cognitive, design-research and practical activities of students is based on authentic material and material with an ethnocultural component. The study involved first and second year students of the Medical Institute of Northeastern University named after M.K. Ammosov 36\% of students defending creative projects rated their skills at 3 points out of 5. Creative projects on the topics My Dream Trip and My Native District and my Village received the greatest response in students (43\%). A total of $36 \%$ of students assessed their knowledge of special terminology (medical) at 3 and 4 on a five-point scale. Improvement in pronunciation and the ability to extract basic information from a text/article (medical) were noted by $43 \%$ of students. Students report difficulties in writing of the main part of annotation and rated their skills at 3 points (36\%), 4 points (21\%), and 2 points (28\%). A total of $64 \%$ of students improved their knowledge on the Republic of Sakha Yakutia due to the geographical lotto used in English lessons. The creative activity approach is implemented by enhancing the cognitive, design-research and practical activities of students based on authentic material and material with an ethnocultural component.
\end{abstract}

\section{Introduction}

According to Chapter 1, Article 10 of the Federal Law "On Education in the Russian Federation" of December 29, 2012. No. 273-F3 established the following levels of professional education: 1) secondary professional; 2) higher education bachelor's degree; 3) higher education - specialty, master's degree; 4) higher education - training of highly qualified personnel According to Chapter 2, Article 10 Structure of the Education System, the education system includes federal state educational standards (FSES) and federal state requirements, educational standards, educational programs of various types, levels and (or) directions [1].

Higher education aims at training of highly qualified personnel in the main areas of socially useful activity in accordance with the needs of society and the state, meeting the needs of the individual in intellectual, cultural and moral development, deepening and expanding education, scientific and pedagogical qualifications (Article 69).

The strategic goal of the Federal State Autonomous Educational Institution of Higher Professional Education North-Eastern Federal University named after M.K. Ammosov (NEFU) in 2010-2019 was its recognition by 2020 at the Russian and international levels as a modern scientific, educational and cultural center of the North East of Russia with a developed innovative, educational, scientific and socio-cultural infrastructure, which provides high-quality training of the personnel capable of development of scienceintensive technologies and modernization of the economic and social sectors of the region [2].

The fundamental ideas of the educators-thinkers I.G. Pestalozzi [3], J.-A. Komensky [4], A.F. Distervega [5], K.D. Ushinsky [6], and others about such pedagogical principles as conformity to nature, cultural conformity and creative activities are reflected in the works by modern researchers: A.P. Bulkina [7], M.N. Vasilyeva [8], V.V. Davydova [9], S.V. Lebedeva [10], N.N. Grigorieva [11], I.S. Rozentseva [12,], etc. The methodological basis of the study: the three-phase structure of activity, the integrity of which is set by the semantic core of the personality in the theory of activity (L.S. Vygotsky [13], A.A. Leontiev [14], A.N. Leontiev [15], S.L. Rubinstein [16], I.A. Zimnyaya [17], etc.); pedagogical concept of A.F. Disterweg about conformity to nature, cultural conformity and amateur performance [18]; the concept of student-oriented learning (E.V. Bondarevskaya [19], I.S. Yakimanskaya [20], L.V. Sidorova [21], etc.); interdisciplinary analysis of multilingualism (M.M. Fomin) [22]; regional features of the system of

Corresponding author: irina_karina@mail.ru 
continuing professional education, theoretical provisions of ethnopedagogy (G.N. Volkov [23], U.A. Vinokurova [24], A.A. Grigorieva [25], D.A. Danilov [26], A.G. Kornilova [27], A.V. Mordovskaya [28], N.D. Neustroev [29], I.S. Portnyagin [30], etc.).

When teaching foreign languages at NEFU for students of non-linguistic specialties, the following fundamental principles of pedagogy are used:

- conformity to nature implies the creation of favorable conditions for identifying the natural abilities of the student, establishing the amount of material studied, the timing of training based on the individual characteristics of the students (interests, abilities) (J.-A. Komensky (1592-1670), A.F. Disterweg (1790-1866));

- cultural conformity implies education and training based on the cultural traditions of the people, their language and religion; provides for training in the context of culture, orientation of education to the nature and values of culture, to mastering its achievements and its reproduction, to the adoption of socio-cultural norms and the inclusion of a person in its further development (A.F. Disterweg);

- creative activities allow students to focus on independent cognition in order to choose the ways and means of self-education [18];

- comparison of languages and cultures is considered as a cognitive process, reflection of differences in the cultures compared. The process of cognition takes place in comparison. Native culture is the basis for mastering the culture of the country of the foreign language (M.M. Fomin) [22].

The paper considers the creative activity approach in teaching English language for students of nonlinguistic specialties at NEFU in the following pedagogical conditions:

- activation of cognitive, design-research and practical activities of students is based on authentic material and material with an ethnocultural component.

According to V.V. Davydova, A.F. Disterweg used the achievements of German classical philosophy (Fichte) to introduce the concept of creative activities into his pedagogy. The natural development of abilities in the process of upbringing and education is associated with the development of mental independence and the ability to reason independently [9, p. 88]. "Creative activity through sensory knowledge and based on the latter. 1) Creative activity as a form of spiritual activity; 2) direct, sensory, living knowledge (content); 3) independent thinking on the basis of sensory cognition, and, conversely, with greater maturity: the creation of visual representations based on everything considered" [5, p. 152].

Among Soviet philosophers and psychologists, ideas of L.S. Vygotsky on the role of activity in the upbringing of children and ideas of S.L. Rubinstein about creative amateur performances are close to those of A.F. Disterweg. According to L.S. Vygotsky, the main figure in education is the child himself as a subject of his own activity supported by the teacher. "Hence, the teacher faces two tasks: first, the individual study of all special features of each student, and second, the individual adaptation of all methods of education and the impact of the social environment on each of them" [13, p. 348]. In the work "Creative activity approach", S.L. Rubinstein examines this approach in terms of the main question of philosophy, the relationship between cognition and its subject, based on Kant's transcendental idealism. The subject is revealed and manifested not only in his deeds and creative initiative, but he is also created and determined. "The activity that defines the object for which it is performed also determines the subject who acts; working on it, he defines not only the object, but also himself" "[16, p. 94].

E.V. Bondarevskaya in her work "Value foundations of student oriented education" reveals the concept of a person of culture. "Personality is creative and thinks variably, ... with a developed sense of the new, a desire to create. Creativity is manifested in all spheres of life ... Pedagogically significant features of a creative personality are concentrated in developed abilities, needs for transformative activities, a fairly large amount of acquired knowledge, skills ... the ability and desire to create life" [19, p. 31].

According to L.V. Sidorova, "student oriented learning aims to promote the development and selfdevelopment of students based on their foreign language experience as subjects of independent activity." Student oriented learning stimulates students for independent learning activities by completing tasks that develop self-knowledge, self-study, selfeducation, self-correction and self-control of students [21, p. 22].

We believe that the creative activity approach is optimally and effectively implemented in the process of teaching foreign languages, since there is an emphasis on active independent, personally meaningful activity within the framework of student oriented learning. "Activity, above all labor, must be actively taught and learned. Activity, labor in particular, ensures the development of cognitive activity, the formation of a system of attitudes towards people, society and, ultimately, the formation of the personality itself "[31, p. 45]. Students actively interact with each other, as well as with the teacher, and at the same time they are a subject of educational, cognitive, creative activity.

In this study, we rely on the main provisions of ethnopedagogy considered by G.N. Volkov [23], U.A. Vinokurova [24], D.A. Danilov [26], A.V. Ivanov [26], A.V. Mordovskaya [28], I.S. Portnyagin [30], I.P. Chabyev [26], and others.

G.N. Volkov, the founder of ethnopedagogy as a scientific discipline, considers the principle of conformity to nature as the highest principle of folk pedagogy (ethnopedagogy). The scientist believes that 
ethnopedagogy is based on the best folk traditions, customs and rituals [23].

In the monograph by the Yakut scientist I.S. Portnyagin "Ethnopedagogy "Kut-sur" pedagogical views of the Sakha people", the pedagogical ideas of the people arising from the traditional worldview and attitude of the Yakuts are analyzed, and the studies of Aiyy and the school "Kut-sur" are theoretically generalized [30].

Since ancient times, the pagan Yakuts have treated nature as a living being, deified it, treated it with deep respect, even with fear of spirits of the forest and its inhabitants. All objects and phenomena of nature that directly affect human well-being have their own icchi (spirits) - lakes, rivers, water, wood, forests, stones, land, every mowing area, mountains, etc. [30, p. 22].

According to A.V. Mordovskaya, "the principle of conformity to nature in folk pedagogy was reflected in two aspects: first, the Yakuts believed that people are part of nature. Children were brought up to treat nature with care, since man is part of it. People believed that nature is the source of their existence. Second, upbringing had a nature-conforming character in accordance with the internal, social situation of the child. In upbringing, the age and sex of children were taken into account" [28, p. 65].

As we have discussed in the work "Methods of communicative competence development in nonlinguistic specialties" [32. p. 795], the main task in teaching a foreign language is the formation of foreign language communicative competence, i.e. the ability to communicate verbally and in writing with representatives of other cultures. When studying foreign language, a graduate of higher education must acquire universal competence (UK-4).

To achieve this goal, it is necessary to implement specific tasks:

1. To form cognitive interest and conscious motives for learning foreign language in a nonlinguistic university.

2. To provide an understanding of the features of the world from the standpoint of foreign language.

3. To increase the level of general culture and education of students, as well as their culture of thinking, communication and speech in familiarizing themselves with the spiritual and material culture of previous generations, with the world, local and national cultures.

4. To ensure the assimilation of moral norms and rules of behavior in society by the individual, to form a tolerant attitude towards the spiritual values of the country of foreign language.

\section{Materials and methods}

The study involved 43 first and second year students who study English at the Medical Institute of Northeastern University named after M.K. Ammosov.
The main research methods: analysis of scientific and methodological literature, observation, testing, conversation with students, surveying. English language lessons were conducted so that oral and written communication with representatives of other cultures was carried out by activating the cognitive, design-research and practical activities of students based on authentic material and material with an ethnocultural component.

Let us consider the implementation of this condition in practical lessons in the discipline Foreign language (English). Students of the first and second years studying English were surveyed upon completion of the discipline. According to the curriculum, they study the discipline for 2 semesters. The survey involved 43 students, who were asked to answer 20 questions.

Questionnaire: \#1 and 2. Name and e-mail. \#3. Rate the degree of need for English in your professional activity, on a scale from 1 to 5 , where 1 is the minimum value and 5 is the maximum one. \#4. Rate the degree of need for English OUTSIDE professional activity, on a scale from 1 to 5 , where 1 is the minimum value and 5 is the maximum one. \#5. Rate your speaking skills based on the results of mastering the course (from 1 to 5 for each item): 1 . Sufficient vocabulary to conduct a conversation on general topics; 2. Sufficient vocabulary to conduct a conversation on professionally oriented topics, for example, a dialogue between a doctor and a patient / in a hospital / in a pharmacy, etc. 3. Public speaking skills (presentation); 4. The use of English for solving problems in various fields of activity. \#6. Rate your listening skills (listening comprehension) based on the results of mastering the course (from 1 to 5 for each item): 1. Perception of oral messages spoken at an average speed on general topics; 2. Perception of oral messages on professionally oriented topics (medicine, specialty when watching videos on YouTube); 3. Determination of the topic of the message, highlighting the main idea; \#7. Rate your reading skills (authentic articles) based on the results of mastering the course (from 1 to 5 for each item): 1 . Pronunciation; 2. Extraction of basic information from a text / article (medicine, specialty); 3 . Search for the necessary information in the text / article when answering questions; 4 . Ability to make a translation of an authentic article "at sight" from an Englishlanguage site.

\#8. Rate your writing skills (authentic articles) based the results of mastering the course (from 1 to 5 for each item): 1. Writing the introductory part of annotation; 2. Writing the main part of annotation using clichés; 3. Writing the final part of annotation using certain phrases. \#9. Rate your skills of independent creative work when performing presentations (projects) based on the results of mastering the course (from 1 to 5 for each item): 1 . Ability to correctly tell the presentation plan using 
cliché phrases; 2. Ability to defend the project; 3 . Ability to answer questions about the presentation. \#10. Assess your involvement / interest in the implementation of the following projects: 1. Englishspeaking Country (The USA, Great Britain and the Northern Ireland, Canada, Australia, New Zealand); 2. Sightseeing of an English-speaking Country; 3. Freetopic; 4. My Dream Trip; 5. My Native District (Ulus) and my Village; 6. The Republic Sakha (Yakutia): Sightseeing; 7. Oral Disease; 8. Grammar Presentation (choice). \#11. Rate your knowledge of specialized terminology in English within your specialty based on the results of working with authentic articles on a fivepoint scale. \#12. Rate your knowledge in the Grammar section based on the results of mastering the course on a five-point scale. \#13. Rate your knowledge of "My Yakutia" (geographic lotto in English) on a five-point scale. \#14. Compare your level at the beginning of studies and now, have you improved your knowledge, skills and abilities in English? 1) Yes, definitely; 2) More likely yes than no; 3) At the same level; 4) More likely no than yes. \#15. Rate the implementation of the Russian online school (Skyeng) in the learning process in English lessons: 1. I liked it 2. I didn't like it 3. I don't know. \#16. Rate your progress in Unit 7 Recoveries and Discoveries: Lesson 1 Long Recovery (Skylike A2-B1) on a five-point scale. \#17. Rate your progress in Unit 13 Health and Medicine (Modals, 6 Folk Rissian virus "cures", Doctors Debunk 15 Flu Myths (Good Vibes B2) on a five-point scale. \#18. Rate your knowledge of Conditionals (Lego Grammar A2) on a five-point scale \#19. What did you learn during the period of study: your achievements and victories \#20. Your wishes / opinion about the course. What was interesting for you? Useful? Difficult? Boring?

\section{Results and discussion}

In this study, we focus on questions \# 9, 10, 11, 7, 8 and 13, which are of direct significance for activation of cognitive, project-research and practical activities of students based on authentic material and material with an ethnocultural component.

Let us analyze the results of students' answers to these questions. Question \#9. Rate your skills of independent creative work in making presentations (projects) based on the results of mastering the course (from 1 to 5 for each item).

When defending creative projects, we evaluated three skills: 1. The ability to correctly tell the presentation plan using cliché phrases when listing the main points of the presentation. For example: Firstly, I'll start with telling about.... Secondly, I speak about.... Then, some information will be spoken about... Next, I tell you about.... Finally, I show... At the end there will be a conclusion... 2. The ability to defend the project; 3 . The ability to answer students questions after the presentation.

For these skills, the most common rate was 3 out of 5 , which was $36 \%$. One student $(7 \%)$ still had difficulty answering questions and rated this skill at 1 out of 5. A total of $14 \%$ of those surveyed rated the ability to answer questions at 5 and $21 \%$ of them rated at 5 . Also, $28 \%$ of students rated their ability to use clichés correctly and speak in front of audience with projects at 4 out of 5 .

Question \#10. Rate your involvement / interest in the implementation of the following projects on a fivepoint scale. The creative projects on the topics My Dream Trip and My Native District (Ulus) and my Village received the greatest response in students $(43 \%)$. The interest in the implementation of the above projects was estimated at 5 points. The second place was occupied by the topics: Sightseeing of an Englishspeaking Country, Free topic, The Republic Sakha (Yakutia): Sightseeing, Oral Disease and Grammar Presentation. Each of these topics scored 36\%. The topics such as English-speaking Country (The USA, Great Britain and the Northern Ireland, Canada, Australia, New Zealand), The Republic Sakha (Yakutia): Sightseeing, Oral Disease and Grammar Presentation rated 4 points with $28 \%$ interest, with 2 points and $14 \%$ interest in all topics except the first one.

Question \#11. Rate your knowledge of specialized terminology in English within your specialty based on the results of working with authentic articles on a fivepoint scale. A total of $36 \%$ of students rated their knowledge of special terminology (medical topics) at 3 and 4 on a five-point scale. Only 2 students (14\%) rated at 5, and two student rated at 1 and 2, respectively. At the end of each month, the student is to submit an article on medical topics, according to his profile. For example: dentists should find an article related to diseases of the oral cavity, etc., pharmacists find articles about plants or medicines, students of the General Medicine department find articles about diseases (common, rare or aroused diseases). It must be an authentic article from an English-language site (for example, www.English-online, www.medicalnewstoday.com, www.nejm.org, www.familydoctor.org, www.topdoctors.co.uk, etc.). The student is to compile a dictionary of 30-50 words and compose annotation. For those students who have difficulty in writing annotations, a template with a set of cliches is offered.

The number of characters in an article depends on the term. The first year students begin to hand in articles from the second term, monthly from January. Number of characters - 1500-2000; February - 2000 2500; March-April-May - 2500-3000. The second course - (term 3) September - 3000-3500; October 3500-4000; November-December - 4500-5000.

A template for writing annotation is as follows. I'd like to tell you about my news article. The title of the 
article is... It was published in... .. (www: Englishonline.at) on... .. (date). The author (s) is (are) ... ..who is (are) well-known researchers (doctors / scientists) in the field of medicine. The article is addressed to people who are interested in this topic / disease / students of medical institutions.

The main idea of the article is... .The article consists of... parts. It starts / begins with information that ... Then the author writes about ... ...Much attention is given to the problem / issue of to (according to part 1) the article ...... The writer describes... . The next paragraph is about.... The author shows that... .After that he discusses (discusses)... ..The article emphasizes the problem of ..... The article ends with... The purpose (aim, objective) of the article is to provide... The article is illustrated with diagrams (charts, photographs, tables) information about...

Now I'd like to tell my own opinion. This article is informative and useful. Firstly, I found out that... .Secondly, I've chosen this topic because.... I agree that ... I disagree with ...

On the day of the defense (once a month, the last lesson), the student reads, translates "at sight" a small paragraph at the beginning of the text, tells 15 words by heart from a compiled dictionary, annotates, and answers questions on the article.

Question \# 7. Rate your reading skills (working with authentic material) based on the results of the course (from 1 to 5 for each item).

Students who rated their skills at 4 points showed the following: $43 \%$ of students noted improvement in their pronunciation and the ability to extract basic information from the text/paper (medical). The search for the necessary information in the text/paper was reported by $36 \%$ of the students when answering the questions. The ability to make a general translation of the authentic text from an English-language site "at sight". However, only $14 \%$ of the students can do "at sight" translation. At the same time, $50 \%$ of the students rated their translation skill at 3 points.

Question \# 8. Rate your writing skills (working with authentic papers) based on the results of mastering the course (from 1 to 5 for each item): 1 . Writing the introductory part of annotation; 2. Writing the main part of annotation using clichés; 3 . Writing the final part of annotation using certain phrases. Evaluation of writing skills revealed that most of the students rated their skills at 3,4 and 2 points. Thus, it is difficult for students to write the main part of annotation and they rated their skills at 3 points (36\%), 4 points $(21 \%)$, and 2 points $(28 \%)$. A total of $43 \%$ of students rated their skill of writing the introductory part and the final part of annotation using cliches at 3 points out of 5 .

Question \# 13. Rate your knowledge in the field "My Yakutia (geographic lotto in English) on a fivepoint scale. The loto is a board game designed to play an intellectual, developing game on the geography of Yakutia for schoolchildren, youth and older people.
The authors are Ilyina L.S., an excellent student of the public service of the Republic of Sakha (Yakutia), and Pukhova N., a student of the secondary school No. 17 in Yakutsk.

Medical students, groups PHARM-19 and STO-20, translated 120 cards into English. At present, the loto is used in practical classes in English in the second term for students specialized in Dentistry, and in the third semester for students specialized in General Medicine and Pharmacy, to introduce an ethnocultural component in teaching of a foreign language. In distance practical training, some of the questions were placed on the MOODLE platform.

The loto includes questions related to the most characteristic features of the nature of Yakutia. The questions cover the following topics: the geographical location of Yakutia (for example, What is the highest mountain in Yakutia? (Mt. Pobeda); Yakutia in numbers (for example, What is the total area of Yakutia (3.1 mln sq.km), and other natural monuments of Yakutia (for example, It is a national park on the Lena river in Khangalassky district. There are rock formations there. Their height reaches 220 meters. They stretch $40 \mathrm{~km}$. They are listed in UNESCO's list of world heritage (Lena Pillars), and other geographical terms characteristic of Yakutia (for example, Name the place that is a lowland surrounded by forest and with lake in the middle (Alaas), etc.); location and geographical features of uluses (regions) of RS (Y) (for example, This ulus is located in the north of the republic beyond the Artic Circle. The Lena river, the Olenek river are the large rivers which flow through the territory of the district. This area is also called the sea gate of Yakutia (Bulunsky district), etc.).

\section{Conclusion}

The obtained results indicate that the creative activity approach in teaching foreign languages for students of non-linguistic specialties activate the cognitive, design-research and practical activities of students based on authentic material and material with an ethnocultural component.

The obtained data are consistent with the opinion of N.A. Lukina that “... this is a great opportunity to use the English language as a means to search for new knowledge in professional activity. In this context, research and search activities of students are developed through active mental work" [33, p. 218].

The student's attention is focused on real communication situations in project works on the study of cultural aspects of a foreign language. The determining factor is an intellectual and creative approach to solving tasks with productive and creative tasks. The creative activity approach was effectively implemented in the process of teaching English, since one of its most important features was the emphasis on active personally significant activity. 


\section{References}

1. Federal Law On Education in the Russian Federation, retrieved from: http://docs.cntd.ru/document/902389617

2. Development program of the Federal State Autonomous Educational Institution of Higher Professional Education "North-Eastern Federal University named after M.K.Ammosov" for 2010 - 2019, Retrieved from: https://www.s-vfu.ru/universitet/rukovodstvo-istruktura/strukturnye-

podrazdeleniya/progr_razv/dokumenty/ПР\%20 СВФУ.pdf

3. I. G. Pestalozzi, Selected pedagogical works. (Moscow, Pedagogika, 1981)

4. Ya. A. Komensky Selected pedagogical works. (Moscow, Publishing House of the Ministry of Education of the RSFSR, 1955).

5. A. Disterweg Selected pedagogical works. (Moscow, Uchpedgizd., 1956).

6. K.D. Ushinsky Pedagogical works: in 6 volumes. (Moscow, Pedagogika, 1988)

7. A.P. Bulkin Cultural conformity of education. Pedagogical experience of Russia in the XVIIIXX centuries: dissertation, (Moscow, 2003)

8. M.N. Vasil'eva Cultural conformity as a principle of education in Russian gymnasiums of the XIX century: dissertation, (Rostov-onDon, 2002).

9. V.V. Davydov Works by A. Disterweg and modern pedagogy Pedagogy 1-2,85-89, (1992)

10. S.V. Lebedev Principle of conformity to nature in ecological education (historical and pedagogical aspect). $\mathrm{PhD}$ dissertation (Moscow, 1999)

11. N.N. Grigorieva Formation of intercultural competence of senior pupils: Dissertation, (Kazan, 2004).

12. I.S. Rozentseva Formation of professional communicative competence of linguistic students on the basis of culture-like technologies: Dissertation (Stavropol, 2004)

13. L. S. Vygotsky Educational psychology. Moscow, (Pedagogika, 1991).

14. A.A. Leontiev Language and speech activity in general and educational psychology (Moscow: NPO MODEK Publishing House, 2003).

15. A.N. Leontiev Activity. Consciousness. Personality. (Moscow, Politizdat, 1975).

16. S.L. Rubinstein Principle of creative amateur performance. To the philosophical foundations of modern pedagogy Issues of Philosophy, 4, 88-95, (1989)

17. I. A. Zimnyaya Lingvistic psychology of speech activity. (Moscow, Moscow Psychological and Social Institute, Voronezh: NPO MODEK, 2001).
18. A. Disterweg Selected pedagogical works. (Moscow, Uchpedgizd., 1956)

19. E.V. Bondarevskaya Value foundations of personality-oriented education Pedagogy, 4, 29-36, (1995)

20. I.S. Yakimanskaya Development of personality-oriented learning technology Issues of psychology, 2, 31-42, (1995).

21. L.V. Sidorova Personality-oriented organization of independent work of students of non-linguistic universities in the process of studying a foreign language (based on the English language) (Yakutsk, 2017)

22. M.M. Fomin Teaching a foreign language in conditions of multilingualism (bilingualism). (Moscow, World of books, 1998).

23. G.N. Volkov Ethnopedagogy. (Moscow, Academy, 2000).

24. U. A. Vinokurova Tale of the Sakha People. (Yakutsk, Bichik, 1994).

25. A.A. Grigorieva On the problem of personalityoriented teaching of a future teacher Public education of Yakutia, 4, 40-43, (1999).

26. D.A. Danilov, A.V. Ivanov, I.P. Chabyev Development of ethnic self-awareness of adolescents in the pedagogical process (based on the material of the Yakut school). (Yakutsk, Yakutsk University Publishing House, 2003).

27. A.G. Kornilova Pedagogy of social work in the rural sphere (based on materials from the Republic of Sakha). (Moscow-Yakutsk, 1997).

28. A.V. Mordovskaya Ethnopedagogical conditions for the formation of life and professional self-determination of senior pupils (on the example of $R S(Y)$ ): dissertation. (Moscow, 2000).

29. N.D. Neustroev, V.V. Akimov Productive labor of rural schoolchildren: pedagogical aspects. (Moscow, Academia, 2001).

30. I.S. Portnyagin Ethnopedagogy "kut-sur": pedagogical views of the Sakha people. (Moscow, Academia, 1998).

31. V.A. Rotenberg, V.M. Clarin Pedagogical heritage of I.G. Pestalozzi. Selected pedagogical works: in 2 volumes. (Moscow, Pedagogika, 1981).

32. I.F. Borisova, O.N. Dmitrieva, V.E. Maksimova, I.L. Savvina, A.R. Sivtseva Methods of communicative competence development in non-linguistic specialties. $X X$ International Scientific Multidisciplinary Conference on Earth and Planetary Sciences SGEM 2020

33. N.A. Lukina Practice-oriented approach in teaching foreign languages to future civil engineers using case technology World of Science, Culture and Education 6(85) 216218. (2020) 